\title{
Appraisal of Environmental Related Issues in Social Science Subjects in Secondary Schools in Nigeria
}

DOI: https://doi.org/10.47175/rielsj.v1i1.29

\author{
${ }^{1}$ Department of Social Science \\ Education Adekunle Ajasin \\ University Akungba Akoko \\ ${ }^{2}$ Department of Sociological \\ Studies Tai Solarin University \\ of Education ljagun, Ogun \\ State, Nigeria \\ 1/anree2007@gmail.com \\ 2adediranyo@tasued.edu.ng
}

| Samuel Olanrewaju Oladapo | Yinka Oluranti Adediran² |

\begin{abstract}
Environmental conservation and management should be a vital component of our school curriculum as a way of investing in our youth so that they can be capable custodians of our environment for the sake of environmental management and conservation for sustainability. The youth have great potential which can only be ignored at our nation's peril. Given that the environment is our greatest heritage, all measures including EE education must be taken serious to ensure that our youth have the correct attitude towards the environment since our very survival depends on this, this should be included in the school curriculum at all level. This research work investigates how environmental education can be used as a tool to create awareness and participation of secondary school students in environmental management and conversation. The research design used in this study was descriptive research design of survey type, to examine the curriculum content of secondary school on environmental conservation and management in secondary schools in Ondo State. The population for the study consists of all the secondary school students in Ondo state. Samples of forty-eight (480) students were drawn from ten (10) selected schools by using stratified random sampling technique. Forty-Eight (48) students were drawn from each of the selected schools. The research instrument used for this study was a self-constructed questionnaire for the students of the selected secondary schools. A sect of questionnaire was design, the questionnaire consisted of two sections; $A$ and B: Section $A$ contained the personal data while Section $B$ contained items constructed in four point linkert scale. Findings from the study reveals among others that there are topics related to conservation in social sciences subjects in secondary schools, that majority of teachers are aware of this and also like teaching it. It therefore, recommend that curriculum planners should make topics on environmental issues be made compulsory at all levels of the education.

KEYWORDS

Appraisal; Social Science Subjects; secondary schools; Nigeria
\end{abstract}

\section{INTRODUCTION}

The public is required to be sufficiently sensitized about the multiple dimensions of environment and development, in order to achieve sustainable development and environmental conservation policies, objectives and targets. Rapid globalization, urbanization, population growth, unsustainable consumption patterns and poverty are at the dawn of the $21^{\text {st }}$ century, a powerful and complex web of interactions that has contributed to unprecedented global trends in environmental degradation (UNESCO, 2012). They have 
served to compound the effects and intensity of the global environmental problems. Depletion of the ozone layer, global climate change, desertification, loss of the planet 's biological diversity, deforestation, trans-boundary movements of hazardous wastes and chemicals are all environmental problems that touch every nation and adversely affect the lives and health of their populations (UNEP, 2012).

In education, some of the desired behaviors are sharply defined e.g. skills useful in reading and mathematics. Other desired behaviors are more complex e.g. successful consumerism, productive employment, responsible citizenship (Erol and Gezer, 2006). The ultimate aim of education is shaping human behavior and the society throughout the world established educational system in order to develop citizens who will behave in desirable ways. In reaction to the myriad environmental challenges, EE was set up with primary goal to empower the world population to maintain and improve environmental quality.

Social Science subjects are subjects that deal with human behavior, unlike sciences and Arts subjects, its curriculum is basically on changing human behavior. Therefore, it curriculum contents comprises and not limited to teaching on issue concerning the environment. The subjects include Geography, Economics, Social Studies and many others. Social Studies which some authors define as social science simplified among other definition is define as the study of man in his environment. It is doubtful if the students studying these subjects are aware if they are being taught environmental conservation. Hence, this study is aimed at appraising this. Oladapo (2020)

Basically conservationists face the difficult task of determining what plan of action to be used to protect the natural riches of the tropics and promote their sustainable use and social justice, Given the biological diversity of tropical ecosystems and the multiple threats to these systems. Education is frequently created as an integral part of the solution. Around the globe, environmental education has become a popular plan of action for promoting the conservation of biological diversity. For example, international conservation organizations such as Conservation International (CI) and World Wildlife Fund (WWF) have provided support for local educational efforts around the globe. Likewise, the Peace Corps is striving to make environmental education an integral part of their programs. Even within academia, researchers have recognized the need to move beyond pure research and participate in educating the public about conservation issues. At the national level, governmental organizations are integrating environmental education into their mandates. The focus of this study, is no exception. The mandate of the national Curricular Reform, Under the direction of the Ministry of Education, Environmental education is being integrated throughout the curricula as an interdisciplinary theme at all grade levels. In addition to these governmental actions, conservation organizations are visible actors in the environmental education arena. Recognizing the opportunity provided by the new Curricular Reform, national and grassroots conservation organizations have mobilized to help teachers and schools meet this new requirement.

The level of global environmental challenges is now beyond serious scientific dispute. In cognizance of the role of an informed and educated citizenry in making appropriate environmental decisions and adopting behavioral approach in addressing environmental challenges, the concept of Environmental Education (EE) was born (Crompton and Kasser, 2009). Environmental Education refers to education efforts that increase public awareness, concern, and knowledge about environmental issues and provides the critical thinking, problem-solving and decision-making skills needed to make responsible decisions about the environment. In secondary school, environmental education/knowledge should be a focused subject within the sciences, Social Sciences and Humanity. (Nwachuckwu 2014).

The ultimate aim of education is shaping human behavior. Societies'throughout the world established educational system in order to develop citizens who will behave in 
desirable ways. In education, some of the desired behaviors are sharply defined e.g. skills useful in reading and mathematics. Other desired behaviors are more complex e.g. successful consumerism, productive employment, responsible citizenship (Erol and Gezer, 2006). In response to the myriad environmental challenges, United Nations Conference on the Human Environment held in Stockholm in 1972 urged all countries of the world to incorporate EE in their curricula at all levels of education. There is no doubt that education will be a tool to combat environmental degradation, climate challenges, flooding, indiscriminate dumping of refuse, poor knowledge on the environment refuse among other (Oladapo, 2012).

The importance of Environmental Education (EE) is seen and emphasized as one of the most effective ways, if not the only way, to meet the complicated problems of the environment. The call for EE is therefore a call for local, regional and global action in response to the biophysical and social problems of the abused environments of the whole world. It is a call to educational system that fosters or encourages the development of environmentally literate citizens who share concern for the environment in which they live and in which future generations will also have to live (Crompton and Kasser, 2009). EE finds its formal root in the United Nations Conference on the Human Environment in Stockholm of 1972. This conference recommended establishment of an International Environmental Education Programme (UNEP, 1972). IEEP was launched in 1975. It recommended the primary categories of environmental education curriculum goals and objectives comprising of environmental awareness, attitudes, skills and participation, which comprise the subject of this study (UNESCO, 1999).

However, for school children to meaningfully participate in environmental management and conservation activities, they require knowledge and skills gained through EE. These qualities are personal thought, feeling and action which develop in the students through an educational process that creates awareness, develops attitude and builds capacity and willingness to take action as an individual and as a group (Toili, 2007). Furthermore, secondary school students are usually receptive and strongly motivated and are capable of understanding the implications of environmental destruction and of trying to take preventive action.

The first form of Environmental Education attempts to transfer knowledge through teaching subjects which refer to the environment on scientific fields e.g. Physics, Geography Chemistry, Biology, Geology, as well as to Social Sciences and Humanities, e.g. Social Studies, Economics and History. The second form of Environmental Education appears through activities realized in the environment as such, where the participants can experience it, its value and its problems directly and personally by assuming activities within it. Last but not least, the third form is about our moral attitude towards the environment and it deals with shaping ecological values, attitudes and behaviors.

According to the Environmental Education Scope and Sequence Expectations (2009), EE can be infused in the following disciplines: The Art, English, Guidance and Career Education, Interdisciplinary Studies, Mathematics, Native Studies, Science, Social Sciences, Humanities, and Technological Education. The problem is not that it is not embedded in the curriculum, but that some teachers find different reasons for not implementing it. Integration of EE requires a strong social network that purports strong allegiance to the environment; a strong environmental philosophy for teachers and students; bridging research and praxis and filling in the gaps with recent research (Stevenson, 2007).

The first form of Environmental Education attempts to transfer knowledge through teaching subjects which refer to the environment on scientific fields e.g. Physics, Geography Chemistry, Biology, Geology, as well as to Social Sciences and Humanities, 
e.g. Economics and History. The second form of Environmental Education appears through activities realized in the environment as such, where the participants can experience it, its value and its problems directly and personally by assuming activities within it. Last but not least, the third form is about our moral attitude towards the environment and it deals with shaping ecological values, attitudes and behaviors

Environmental conservation and management should be a vital component of our school curriculum as a way of investing in our youth so that they can be capable custodians of our environment for the sake of environmental management and conservation for sustainability. The youth have great potential which can only be ignored at our nation's peril. Given that the environment is our greatest heritage, all measures including EE education must be taken serious to ensure that our youth have the correct attitude towards the environment since our very survival depends on this, this should be included in the school curriculum at all level.

As efforts to intensify Environmental conservation and management in schools through multidisciplinary approach have continued to increase over the years, a varied feedback has been received regarding students' level of awareness, attitudes and participation in environmental activities. According to the findings of the study done by Sarkar in Bangladesh, it was noted that students in urban centers are more environmentally informed compared to those in rural areas. While rural-urban differences household characteristics are still a significant determinant of differences in school participation patterns based on past researches, there is now a growing urban-urban divide following rapid urbanization.

This necessitates the need to establish the relationship across the nation either urban or rural area. This is essential in establishing the special and unique characteristics and features of various region/area in order to determine how best to use EE to address environmental problems in different region/area.

\section{Purpose of the Study}

This research work investigates how environmental education can be used as a tool to create awareness and participation of secondary school students in environmental management and conversation.

\section{Objective of the Study}

The following are the objectives of this research work:

1. to investigate the inclusion of environmental education into secondary school curriculum

2. to examine secondary school student's attitudes towards environmental management and conservation

3. to examine the various sources of information on Environmental management and conservation among secondary school students

\section{Research Questions}

The following are the questions this research work aim to provide answers to:

1. Is there environmental education courses in secondary school curriculum?

2. What are the attitudes of secondary school students towards courses on environmental management and conservation in the curriculum?

3. What are the various sources of information on Environmental management and conservation for secondary school students? 


\section{Significance of the Study}

The findings of this study will be useful because of the urgent need to encourage change in behaviour and attitude in regard to the environmental management and conservation. It will also help students to appreciate and enjoy the world around them.

Policy makers would also benefit from the findings by acquiring the knowledge to help them adopt necessary environmentally friendly policies and approaches.

From the research, teachers will know the type of learning experiences that help to develop active and informed minds to help pupils and students understand, appreciate, and care for the environment.

The government through the ministries of Education and Environment, curriculum developers and implementers will also be able to identify the shortcomings of EE at this level with a view of rectifying the situation including the fixing of existing assumptions.

\section{METHOD}

The research design used in this study was descriptive research design of survey type, to examine the curriculum content of secondary school on environmental conservation and management in secondary schools in Ondo State.

\section{Population of the Study}

The population for the study consists of all the secondary school students in Ondo state.

\section{Sample and Sampling Techniques}

Samples of forty-eight (480) students were drawn from ten (10) selected schools by using stratified random sampling technique. Forty Eight (48) students were drawn from each of the selected schools.

\section{Research Instrument}

The research instrument used for this study was a self-constructed questionnaire for the students of the selected secondary schools. A sect of questionnaire was design, the questionnaire consisted of two sections; A and B: Section A contained the personal data while Section B contained items constructed in four point linkert scale and the respondents are to tick the best option out of:

Four (4) point linkert scale: Strongly Agree (SA), Agree (A), Strongly Disagree (SD), Disagree (D)

\section{RESULTS AND DISCUSSIONS}

This chapter presents the findings and discussion on the data gathered during the course of the research.

Research Question 1: Is there inclusion of environmental education into secondary school curriculum?

Table 1. A frequency table showing inclusion of environmental education into secondary school curriculum

\begin{tabular}{|c|c|c|c|c|c|c|c|}
\hline $\begin{array}{l}\mathbf{S} / \\
\mathbf{N}\end{array}$ & $\begin{array}{l}\text { Inclusion of environmental } \\
\text { education in secondary school } \\
\text { curriculum }\end{array}$ & SA & $\mathbf{A}$ & D & SD & Mean & Std.D \\
\hline 1 & $\begin{array}{l}\text { Environmental Education is one } \\
\text { of the subjects we offer in school }\end{array}$ & $20.8 \%$ & $77.1 \%$ & $0 \%$ & $2.1 \%$ & 3.17 & .52 \\
\hline 2 & $\begin{array}{l}\text { Environmental Education is a } \\
\text { compulsory topic in secondary } \\
\text { school curriculum }\end{array}$ & $27.1 \%$ & $54.2 \%$ & $14.6 \%$ & $4.2 \%$ & 3.04 & .77 \\
\hline
\end{tabular}




\begin{tabular}{llllllll}
\hline 3 & $\begin{array}{l}\text { Environmental Education is taught } \\
\text { in some subjects in the school }\end{array}$ & $16.7 \%$ & $81.3 \%$ & $2.1 \%$ & $0 \%$ & 3.15 & .41 \\
4 & $33.3 \%$ & $47.9 \%$ & $12.5 \%$ & $6.3 \%$ & 3.08 & .84 \\
$\begin{array}{l}\text { Universal Basic Education } \\
\begin{array}{l}\text { Curriculum contain EE } \\
\text { programme }\end{array}\end{array}$ & $20.8 \%$ & $52.1 \%$ & $18.8 \%$ & $8.3 \%$ & 2.85 & .85 \\
$\begin{array}{l}\text { Many of the school subject } \\
\text { curriculum contain EE }\end{array}$ & & & & & & &
\end{tabular}

Weighted Mean $=3.06$

The result in table 1 indicated that Environmental education is implemented in secondary school curriculum as revealed in a weighted mean score of 3.06 which is above the standard mean score of 2.50. Students indicated that many of the school subject curriculum contain $\mathrm{EE}$ (mean score=2.85), they were taught $\mathrm{EE}$ in some subjects in school (mean score=3.15), and Environmental Education is a compulsory topic in secondary school (mean score=3.04). Also Environmental Education is offered in school (mean score $=3.17$ ) and that the universal basic education curriculum contain EE (mean score $=3.08)$.

Research Question 2: What is the attitude of Secondary school students toward environmental management and conservation?

Table 2. A frequency table showing attitude of students toward environmental management and conservation

\begin{tabular}{|c|c|c|c|c|c|c|c|}
\hline $\begin{array}{l}\mathbf{S} / \\
\mathbf{N}\end{array}$ & $\begin{array}{l}\text { Students' attitude environ- } \\
\text { mental management and } \\
\text { conservation }\end{array}$ & SA & $\mathbf{A}$ & D & SD & Mean & Std.D \\
\hline 1 & $\begin{array}{l}\text { Teaching/learning of EE helps } \\
\text { us on how to solve } \\
\text { environment issues }\end{array}$ & $27.1 \%$ & $64.6 \%$ & $6.3 \%$ & $2.1 \%$ & 3.17 & .63 \\
\hline 2 & $\begin{array}{l}\text { We collect garbage from our } \\
\text { classroom in the morning and } \\
\text { during breaks and throw them } \\
\text { into bush }\end{array}$ & $20.8 \%$ & $52.1 \%$ & $18.8 \%$ & $8.3 \%$ & 2.85 & .85 \\
\hline 3 & $\begin{array}{l}\text { We collect garbage from our } \\
\text { classroom in the morning and } \\
\text { during breaks and throw them } \\
\text { into the drains }\end{array}$ & $27.1 \%$ & $56.3 \%$ & $6.3 \%$ & $10.4 \%$ & 3.00 & .88 \\
\hline 4 & $\begin{array}{l}\text { We took part in tree-planting } \\
\text { campaigns every time in our } \\
\text { school }\end{array}$ & $14.6 \%$ & $54.2 \%$ & $18.8 \%$ & $12.5 \%$ & 2.71 & .87 \\
\hline 5 & $\begin{array}{l}\text { We participate in Environmental } \\
\text { volunteers and environmental } \\
\text { club in the school }\end{array}$ & $20.8 \%$ & $58.3 \%$ & $16.7 \%$ & $4.2 \%$ & 2.96 & .74 \\
\hline
\end{tabular}

Weighted Mean= 2.94

The result in table 2 indicated that students' attitude towards Environmental Education is fairly positive as revealed in a weighted mean score of 2.94 which is slightly above the standard mean score of 2.50. Although students gather garbage in their classrooms, they throw them into bush and drains (mean score=2.85 and 3.00) respectively. Students, however, fairly participate in tree-planting with mean of 2.71 , they also participate in Environmental Volunteers and environmental club in the school (mean score=2.96). 
Research Question 3: What are the various sources of information on Environmental management and conservation for secondary school students?

Table 3. A Percentage table showing various sources of information on Environmental management and conservation

\begin{tabular}{llllllll}
\hline S/N & $\begin{array}{l}\text { Sources of Information on } \\
\text { Environmental management } \\
\text { and conservation }\end{array}$ & SA & A & D & SD & Mean & Std.D \\
\hline 1 & Through teaching in class & $18.8 \%$ & $72.9 \%$ & $4.2 \%$ & $4.2 \%$ & 3.06 & .63 \\
2 & Through television programme & $22.9 \%$ & $68.8 \%$ & $4.2 \%$ & $4.2 \%$ & 3.10 & .66 \\
3 & Through radio programme & $14.6 \%$ & $75 \%$ & $6.3 \%$ & $4.2 \%$ & 3.00 & .62 \\
4 & $\begin{array}{l}\text { Through the internet and } \\
\text { newspaper }\end{array}$ & $16.7 \%$ & $66.7 \%$ & $14.6 \%$ & $2.1 \%$ & 2.98 & .64 \\
5 & Through worship center & $22.9 \%$ & $56.3 \%$ & $10.4 \%$ & $10.4 \%$ & 2.98 & .87 \\
\hline & Weighted Mean=3.01 & & & & & & \\
\hline
\end{tabular}

The result in table three showed that the classroom, television, radio, internet and newspaper, and worship centers as sources of information on environmental management and conservation with weighted mean score of 3.01 which is higher than the standard mean of 2.50. Television and radio programme were identified as the major source of information with mean scores of 3.10 and 3.00, next to classroom teaching with mean score of 3.06 while internet, newspaper and worship centers were least ranked as source of vital resources for information on environmental management and conservation.

\section{DISCUSSION OF FINDING}

Findings from research question one revealed that there is an indication that environmental education is taught in some subject in secondary school, and is part of universal basic education curriculum programme and many of the school subject curriculum contain environmental education with weighted mean of 3.06. This finding agreed with the study of Drake, (2004). Which stated that Environmental Education draws its content from the subject specific content of each subject. Environmental Education therefore does not replace a particular subject, but is treated holistically through all the areas of understanding and experiences.

Research question two revealed that teaching and learning of environmental related topics helps to solve environmental issues especially among secondary school students, this is in consonance with the study of Nwachuckwu (2014) who state that Environmental Education increase public awareness, concern, and knowledge about environmental issues and provides the critical thinking, problem-solving and decision-making skills needed to make responsible decisions about the environment.

Research question three revealed the source of Environmental Management Conservation information among the students and from the result the following sources were identified; classroom, television programme, radio programme, and internet, while the information from religious center were not as high compare to the other source.

\section{Summary}

This research work investigates how environmental related topics can be used as a tool to create awareness and participation of secondary school students in environmental management and conversation in Ondo State, Nigeria This research adopted descriptive research by using stratified random sampling techniques to select forty-eight (48) students from two (2) schools in the study area for the administration of questionnaire and the result was analyzed using descriptive statistics. 


\section{Findings}

The findings of the study revealed that environmental related topics are in some of the subjects offered in secondary schools. Also environmental related topics helps to solve environmental issues especially among secondary school students, and source of Environmental Management Conservation information are from different source among which area the classroom, television programme, radio programme, internet

\section{CONCLUSION}

It can be concluded from the study that environmental related topics are contained in many subjects been taught in secondary schools.

\section{RECOMMENDATIONS}

All acknowledgments (if any) should be included at the very end of the paper before the references. This section is the place to acknowledge people (dedications), places, and financing (you may state grants and sponsors here).

\section{REFERENCES}

Ajitoni, S.O. and Oladapo, S.O. (2013) Effect of a participatory environmental education programme on traders' waste generation knowledge and disposal practice in Oyo State, Nigeria.

Erol, G. and Gezer, K. (2006). Teachers'Attitudes toward Environment and Environmental Problems. International Journal of Environmental and Science Education, 1(1), 65-77.

Nwachukwu M.A (2014). Prospective techniques for in-situ treatment and protection of aquifers: A sustainable hydrology review. Intl $\mathbf{J}$ of Water Res and Environ Eng; Vol. 6(4), pp.131-143

Oladapo, S.O. (2012). Effect of participatory environmental education programme on knowledge, attitude and practices of traders in solid waste management in Oyo State (Unpublished doctoral thesis), University of Ibadan Nigeria.

Oladapo, S.O. (2014). Environmental knowledge, attitude and socio-cultural beliefs as predictors of social studies students' environmental practices. Akungba journal of research in education. 2.(170-181).

Toili, W.W (2007). Secondary School Students' Participation in Environmental Action: Coercion or Dynamism? Eurasia Journal of Mathematics, Science \& Technology Education, 2007, 3(1), 51-69

UNEP, (2012). 21 Issues for the 21st Century: Result of the UNEP Foresight Process on Emerging Environmental Issues. United Nations Environment Programme (UNEP), Nairobi, Kenya.

UNESCO (1999). Environmental Education and Training in Egypt, UNESCO,Paris. UNESCO (2012). Education Policy Matters. UNESCO, Bangkok.

UNESCO-UNEP (1985). Interdisciplinary Approaches in Environmental Education. Unesco, Paris

United Nations, (1994). United Nations Conference on Environment and Development Rio de Janeiro: Agenda 21, Rio Declaration, Forest Principles (Drafts), UN: Brazil.

Yurtta, F., Sülün, Y. (2010). What are the Most Important Environmental Problems According to the Second Grade Primary School Students? Procedia Soc. Behav. Sci., 2: $1605-1609$ 